\title{
Views of a Vector: An Interview with Mavis Agbandje-McKenna
}

\author{
Kevin Davies* \\ Executive Editor, Human Gene Therapy
}

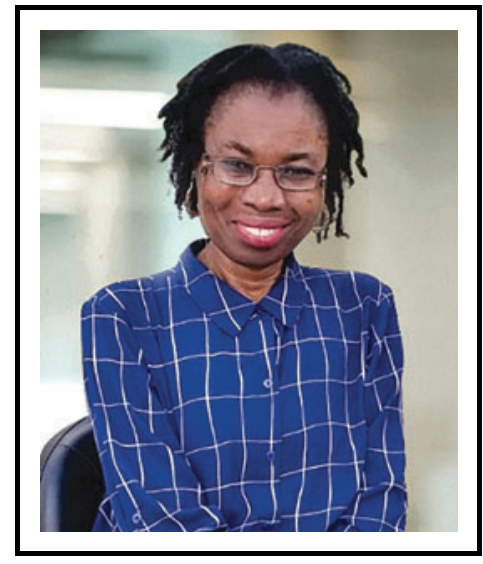

Mavis Agbandje-McKenna
Editor's note: In 1999, Mavis Agbandje-McKenna took a faculty position at the University of Florida. An expert in structural biology, she was invited to turn her talents to the study of adeno-associated viruses (AAVs). Over the next two decades, using cryo-electron microscopy (cryoEM) and other technologies, Agbandje-McKenna and colleagues made a series of key discoveries on the structure-function relationship of AAV vectors. Those contributions have been recognized with the 2020 American Society of Gene and Cell Therapy (ASGCT) Outstanding Achievement Award.

In this interview with Human Gene Therapy's Executive Editor, Kevin Davies, Agbandje-McKenna talks about her career highlights, made all the more remarkable because she is battling amyotrophic lateral sclerosis (ALS). (This transcript has been lightly edited for length and clarity.)
Dr. Davies: Mavis, you did your PhD in London. What made you want to come to America?

Dr. Agbandje-McKenna: Actually, my husband, Robert McKenna! He wanted to come to America after we had completed our PhDs, and he wanted to go to a big structural biology lab. So, we went to Michael Rossmann's lab at Purdue. We didn't want a long-distance marriage. So, I followed him to Purdue, and Michael was willing to give me a positionnothing fancy!

Dr. Davies: Was your PhD in structural biology?

Dr. Agbandje-McKenna: No, not at all. It was in biophysics. Rob was a crystallographer, and I made DNA intercalators at the Royal Marsden, where I got my PhD. I was interested in cancer. When I got to Purdue, I had to learn from scratch, and I started off just making viruses, tissue culture, and then decided I wanted to do the whole thing. I began doing crystallography and then cryoEM.

Dr. Davies: That's an amazing story! Your career didn't come about because you were passionate about structural biology or viruses early on but because you were following your husband! Something must have rubbed off on you?

Dr. Agbandje-McKenna: Absolutely, yes. I loved it. I just thought that to be able to start from scratch, as it were, and get a three-dimensional structure at the end, and then try and figure out what that structure was doing was just fascinating.

Dr. Davies: After a spell back in Britain, in 1999, you joined the faculty at the University of Florida, where you are still. Were you thinking about gene therapy at that time, or was it more just about fundamental structural biology of viruses?

Dr. Agbandje-McKenna: I wasn't thinking about gene therapy at all. I was still interested in pathogenic viruses and trying to understand how they cause disease-what their life cycle is. But then Nick Muzyczka and Ken Berns were there. They said, "We want you to work on AAV." I said, "No, that virus doesn't do

${ }^{*}$ Correspondence: Dr. Kevin Davies, Executive Editor, Mary Ann Liebert, Inc., New Rochelle, New York, USA. E-mail: kdavies@liebertpub.com 
anything. I don't want to work on AAV." It was funny.

But Nick said, "No, you want to work on this." I said, "All right, I'll work on it." Now, we are doing mostly AAV. My hesitation was just because AAV did not cause disease. I was really more interested in pathogenic viruses at the time. But once we started working on it, we realized there was so much to do.

Dr. Davies: Of course, 1999 is the same year that Jesse Gelsinger died. Did that event have any impact on you?

Dr. Agbandje-McKenna: No, I didn't pay much attention, not until later. I wasn't thinking about gene therapy yet.

Dr. Davies: How did you go about studying AAV capsid structure? How did you match the technology with the problem at hand?

Dr. Agbandje-McKenna: We actually did a lot of crystallography when I got here. CryoEM was not really giving us the resolution we needed to understand the virus capsid that much. I did crystallography to get the atomic data on the viruses, and looking at some of the capsid interactions, because I was interested in actually mapping the whole life cycle-cellsurface binding, trafficking, uncoating, assembly-everything.

But as cryoEM came into its own with improved resolution, one of the things we wanted to look at was antibody interactions because that was a big deal, trying to overcome preexisting immunity. CryoEM has given us the perfect application to do that.

Dr. Davies: How big a part does AAV play in the full scope of your research?

Dr. Agbandje-McKenna: It is about $70 \%$ right now. We still work on pathogenic viruses, especially emerging ones. There is human bocavirus, there is bufavirus and cutavirus, tusavirus that belongs to the Parvoviridae, and porcine circle virus 2 and maize streak virus that belong to the Circoviridae and Geminiviridae. That is about a third of what we do.

Dr. Davies: When did your work on AAV change from being focused on fundamental, basic research on a benign virus into something that clearly had real-world therapeutic relevance because of the emergence of $\mathrm{AAV}$ as a leading vector?

Dr. Agbandje-McKenna: That really started in about 2005. I started collaborating with Jude Samulski because he was interested in our structures, and I helped him, based on our structural data, to design AAV 2.5, which was used in the clinic. Around the same time, Arun Srivastava and I started collaborating on his tyrosine to phenylalanine variants, which are also in the clinic now. After that, we've been collaborating with a lot of people who are interested in making vectors and doing in vivo studies.

Dr. Davies: What can cryoEM tell you that $X$-ray crystallography cannot?

Dr. Agbandje-McKenna: CryoEM is just able to study larger macromolecular complexes-complexes that are not amenable to crystallization.

Dr. Davies: When did your research evolve into rationally deciding how to change the properties of the virus to tailor it to your own purposes?

Dr. Agbandje-McKenna: Once we had a good number of structures, and we started looking at similarities and differences relating to tropism and function. Now we could say we know which regions of the capsid to manipulate. So, it has just been having a wealth of information in my hands to be able to manipulate.

Dr. Davies: What have been some of your most important papers over the past 10-15 years? I keep hearing about your 2008 study in PNAS $^{1}$ for example?

Dr. Agbandje-McKenna: That is one of them, absolutely! That study reported our observation that removal of surface tyrosines from AAV resulted in improved transduction. ${ }^{1}$ Another PNAS study, published in collaboration with Aravind Asokan, ${ }^{2}$ is one of the things that led to us forming a company-StrideBiobeing able to map antibody-binding residues on the capsid surface. Mapping where the antigenic regions are is what led to that company. The company is looking at different diseases, including Friedrich Ataxia in collaboration with Takeda.

We were the first to publish the highest resolution structure for a virus determined by cryoEM. ${ }^{3}$ And we also published the highest resolution capsid-antibody structure in $J V I$ for AAV5 complexed with a new monoclonal antibody. ${ }^{4}$ So, we have published a number of firsts.

Dr. Davies: You've specialized in rational capsid design. Is that complementary to other methods such as in vitro selection?

Dr. Agbandje-McKenna: They are. I think, at the end of the day, by using in vitro selection, they showed that we make changes in the same region of the capsid. Nature is very good, and it knows what it wants to do. All I'm saying is that I can do it quicker because we defined capsid regions that tolerate change and play a role in the capsid function during infection! Our work can definitely also inform the in vitro selection strategies.

Dr. Davies: You must be very gratified to see the recent approval of AAV therapies such as Luxturna 
and Zolgensma. Can you believe how far we've come since you began studying AAV?

Dr. Agbandje-McKenna: It is amazing! It took us 47 years from the discovery of AAV to get Glybera approved, I believe. And then another 5 years to get Luxturna, and years later comes Zolgensma. It is an absolutely incredible ride.

Dr. Davies: Where do you think are the current bottlenecks? Is there still a lot of work to be done in terms of designing AAVs, or is the bigger problem on the manufacturing side?

Dr. Agbandje-McKenna: I think what we have now in AAV vectors is good, but right now, I'm focusing on really understanding the interaction of human molecules with the AAVs. There are molecules in addition to antibodies in serum that may affect AAV transduction. We're trying to figure out what else interacts with the capsid that we can see with structure analysis.

In manufacturing, yields can be crazy low, especially for variants. Wild-type capsids are fine. But as soon as you change it, there seems to be a problem. So, that is what we have to do: figure out what it is about the variants that has such an adverse effect on production and purification.
The third issue is genome packaging. How do we improve packaging efficiency? We have tried to increase packaging capacity, but we cannot get much higher than $5.2 \mathrm{~kb}$.

Dr. Davies: You have been just been awarded the ASGCT's Outstanding Achievement Award for 2020 - many congratulations! What does that award mean to you?

Dr. Agbandje-McKenna: I feel so honored to have it, and the fact that the work that we've been doing over the past 20 years has been recognized in this way makes me feel so happy. I'm also happy for all my mentees in the field-I think it makes them feel happy that their work has also been rewarded.

Dr. Davies: What is the most exciting or important avenue of research that you are currently working on?

Dr. Agbandje-McKenna: It is just looking at these human serum molecules with the capsid. I am also working on parvoviruses and other viruses, geminiviruses. That is very exciting.

Dr. Davies: You speak a lot about glycobiology. Is that relevant in the study of AAVs?
Dr. Agbandje-McKenna: Absolutely. AAVs interact with different glycans and glycosylated molecules, and it is the first point of contact for the capsid-before they come into the cell. It is important for us to know what those interactions are on both the capsid and the receptor side. This information aids the engineering of AAV for improved or altered tropism, and also provides information on regions to conserve when modifying the capsid for host immune escape. We are also mapping these interactions for the AAVs as well as other parvoviruses, including $\mathrm{H}-1$ parvovirus, being developed for oncolytic therapy.

Dr. Davies: Mavis, you're facing your own health challenges with ALS. I'm very sorry for that. How are you managing to continue to play such a vibrant role for this community and for your students in overcoming these challenges?

Dr. Agbandje-McKenna: It is very challenging, as you say. I am feeling a lot weaker, as you can see. But I love it. This is what keeps me going. I still have students and postdocs. I have the scientific community in my life, and their interactions keep me going. My former students are in constant contact. I think what we are doing is important. So, that is what keeps me going. I have family here and back in the United Kingdom who support me. I feel loved.

\section{REFERENCES}

1. Zhong L, Li B, Mah CS, et al. Next-generation of adeno-associated virus 2 vectors: point mutations in tyrosines lead to high-efficiency transduction at lower doses. Proc Natl Acad Sci U S A 2008;105:7827-7832.

2. Tse LV, Klinc KA, Madigan VJ, et al. Structureguided evolution of antigenically distinct adeno- associated virus variants for immune evasion. Proc Natl Acad Sci U S A 2017;114:E4812E4821.

3. Tan YZ, Aiyer S, Mietzsch M, et al. Sub-2 A Ewald curvature corrected structure of an AAV2 capsid variant. Nat Commun 2018;9:3628.
4. Jose $A$, Mietzsch $M$, Smith $K$, et al. Highresolution structural characterization of a new adeno-associated virus serotype 5 antibody epitope toward engineering antibody-resistant recombinant gene delivery vectors. J Virol 2018;93: e01394-18. 